\title{
Self-assembled micelles of amphiphilic poly(L-phenylalanine)-b-poly(L-serine) polypeptides for tumor-targeted delivery
}

This article was published in the following Dove Press journal:

International Journal of Nanomedicine

12 December 2014

Number of times this article has been viewed

\author{
Ziming Zhao ${ }^{1,2, *}$ \\ Yu Wang ${ }^{1,2, *}$ \\ Jin $\operatorname{Han}^{1,2}$ \\ Keli Wang' \\ Dan Yang ${ }^{1,2}$ \\ Yihua Yang ${ }^{1,2}$ \\ Qian Du',2 \\ Yuanjian Song ${ }^{3}$ \\ Xiaoxing Yin ${ }^{1,2}$
}

'Department of Pharmacy, ${ }^{2}$ Jiangsu Key Laboratory of New Drug Research and Clinical Pharmacy, ${ }^{3}$ Department of Basic Medical Sciences, Xuzhou Medical College, Xuzhou, People's Republic of China

*These authors contributed equally to this work
Correspondence: Xiaoxing Yin Department of Pharmacy, Xuzhou Medical College, Xuzhou 221004, People's Republic of China

Tel +865I6 83262139

Fax +8651683262257

Email yinxxgood@126.com
Abstract: The aim of this work was to design, synthesize, and characterize self-assembled micelles based on polypeptides as a potential antitumor drug carrier. Amphiphilic poly(L-phenylalanine)$b$-poly(L-serine) (PFS) polypeptides were obtained through the polymerization of $N$-carboxyanhydride. As a novel hydrophilic segment, poly(L-serine) was utilized to enhance tumor targeting due to a large demand of tumors for serine. PFS could self-assemble into micelles with an average diameter of 110-240 nm and a slightly negative charge. PFS polypeptides adopted random coil in $\mathrm{pH} 7.4$ phosphate-buffered saline and could partly transform to $\alpha$-helix induced by trifluoroethanol. PFS micelles with a low critical micelle concentration of $4.0 \mu \mathrm{g} \mathrm{mL} \mathrm{mL}^{-1}$ were stable in $\mathrm{pH} 5-9$ buffers and serum albumin solution. PFS micelles had a loading capacity of $3.8 \%$ for coumarin- 6 and exhibited a sustained drug release. Coumarin- 6 loaded rhodamine B isothiocyanate-labeled PFS micelles were incubated with Huh-7 tumor cells to study the correlation between drugs and carriers during endocytosis. The uptake of drugs was consistent with the micelles, illustrating that the intracellular transport of drugs highly depended on the micelles. PFS micelles diffused in whole cytoplasm while coumarin- 6 assumed localized distribution, suggesting that the micelles could release the loaded drugs in particular areas. The internalization mechanism of PFS micelles was involved with clathrin-mediated endocytosis and macropinocytosis. Excess serine inhibited the uptake of PFS micelles, which demonstrated that serine receptors played a positive role in the internalization of PFS. The more interesting thing was that the uptake inhibition impacted on normal cells but not on tumor cells at the physiological concentration of serine. The difference in the uptake of PFS micelles was fourfold as high between the tumor cells and the normal cells, which indicated that PFS micelles had good tumor targeting in vitro. In conclusion, PFS micelles reported in this work were a promising drug delivery system for tumor targeting therapy.

Keywords: amphiphilic polypeptides, micelles, poly(L-serine), poly(L-phenylalanine), tumor therapy

\section{Introduction}

Chemotherapy is far from an entirely successful treatment for tumor because the therapy is always accompanied by severe side effects and poor quality of life. One major reason is that most antitumor drugs have indiscriminate systemic distribution, thus killing tumor cells and normal cells without selectivity. In addition, poor water solubilities of many antitumor drugs result in a low bioavailability, and the solubilizers in formulation cause severe adverse reactions. Therefore, there is a dire need for the development of suitable drug carriers that can increase the solubility and stability of antitumor drugs and transport them specifically to tumors. ${ }^{1}$ In recent years, nanocarriers resulting from the self-assembly of amphiphilic copolymers have been considered as ideal candidates. ${ }^{2-4}$ 
They can self-assemble into core-shell nanostructures, where the hydrophobic cores serve as containers for hard-soluble drugs and the hydrophilic shells help to avoid being cleared by mononuclear phagocytic system (MPS). ${ }^{5}$

Various polymers and biomacromolecules have been used to compose amphiphilic materials. Thereinto, polypeptides or polyamino acids have particular attraction as components for copolymers owing to some significant advantages. In addition to outstanding biodegradability and biocompatibility, polypeptides or polyamino acids can be manipulated to adopt different secondary structures, which is helpful to stabilize the vehicles and incorporate drugs. Moreover, some peptides with particular sequences, acting as signal peptides or the recognition units of particular receptors, can induce specific interactions with cells..$^{6,7}$

Amphiphilic polypeptides or polyamino acids have been developed to form various nanostructures, such as nanotubes, ${ }^{8,9}$ nanofibers, ${ }^{10,11}$ and micellar nanoparticles (MNPs). ${ }^{12,13}$ Compared with other architectures, MNPs are more suitable for antitumor drug carriers. On one hand, MNPs provide a hydrophobic environment and have a high payload of hard-soluble drugs. On the other hand, the size of MNPs is often below $100 \mathrm{~nm}$, which makes them easy to accumulate within solid tumors owing to the enhanced permeability and retention effect. ${ }^{14}$ Amphiphilic block polypeptides, where poly(alanine) acted as hydrophobic segment and poly(sarcosine) acted as hydrophilic segments, could form spherical aggregates in water, and the structure changed depending on the relative length of the two blocks. ${ }^{15}$ Amphiphilic block polypeptides consisting of hydrophilic poly( $N$-hydroxyethyl-L-glutamine) and hydrophobic poly(L-tryptophan) could form nano-aggregates and exhibited pH sensitivity. ${ }^{16}$ Nanoparticles composed of poly $(\gamma$-glutamic acid) and poly(L-phenylalanine) were efficiently taken up by macrophages and delivered encapsulated protein from the endosome to the cytoplasm. ${ }^{17}$ One kind of $\mathrm{pH}$-responsive micelles based on amphiphilic polypeptides containing lysine and arginine-glycine-aspartic acid sequence in hydrophilic head and poly(valine) sequence in hydrophobic tail could targetedly deliver doxorubicin into tumor cells. ${ }^{18}$

As these samples suggest, various hydrophobic amino acids have been applied in amphiphilic copolymers, such as poly(alanine), ${ }^{15}$ poly(tryptophan), ${ }^{16}$ poly(phenylalanine),${ }^{17}$ poly(valine), ${ }^{18}$ poly(leucine),${ }^{19}$ and poly(histidine). ${ }^{20}$ Compared with hydrophobic moieties, the type of polyamino acids that can be utilized as the hydrophilic segment of amphiphilic copolymers is limited. Poly(glutamate), ${ }^{21}$ poly(aspartic acid), ${ }^{22}$ and poly(lysine $)^{23}$ are the most commonly used materials, but there are few reports on the applications of other suitable hydrophilic polyamino acids in the construction of carriers. Poly(L-serine) has no ionizable groups in side chains, but it is hydrophilic because of the hydrogen bonds between its hydroxyls and water molecules. Thus, the hydrophilic and uncharged poly(L-serine) might help MNPs to escape from the uptake of MPS, just as the function of polyethylene glycol. Moreover, serine is a vital amino acid in the overall metabolism and critical for cell growth and the proliferation of rapidly dividing cells, eg, tumor cells. Recent studies show that at least half of all tumors lack the ability to self-generate serine and cannot adapt to serine starvation. ${ }^{24}$ Therefore, high-affinity serine receptors, such as L-type amino acid transporter 1 and alanine--serine-cysteine transporter 2, are highly expressed in tumor cells versus normal cells. ${ }^{25,26}$

For the above reasons, poly(L-serine) was chosen as the hydrophilic segment and expected to enhance the affinities of the designed copolypeptides to tumors, and poly(L-phenylalanine) served as the hydrophobic segment. A novel amphiphilic copolypeptide, poly(L-phenylalanine)$b$-poly(L-serine) (PFS), was synthesized and proposed as a carrier for antitumor drugs. The characteristic of PFS was confirmed by Fourier transform infrared spectroscopy (FTIR), ${ }^{1} \mathrm{H}$ NMR, and circular dichroism (CD). Self-aggregated micelles based on PFS polypeptides were prepared, and the drug loading ability and release behavior of PFS micelles were investigated. The morphology, property, cellular uptake mechanism, and tumor targeting in vitro of PFS micelles were evaluated in this work.

\section{Materials and methods Materials}

Triphosgene (99\%), tert-butyldimethylsilyl chloride (TBDMSCl, 97\%), 1,8-diazabicyclo(5,4,0)undec-7-ene (DBU, 99\%), tetrabutyl ammonium fluoride (TBAF, $1 \mathrm{M}$ in tetrahydrofuran [THF]), coumarin-6 (laser level), rhodamine B isothiocyanate (RBITC, 99\%), and trifluoroethanol (TFE, 99.5\%) were purchased from Aladdin. Pyridine and sodium azide $\left(\mathrm{NaN}_{3}\right)$ were from Sinopharm. L-Phenylalanine (BR) and L-serine (BR) were purchased from Shanghai Yuanju. Chlorpromazine hydrochloride (CPZ, 98\%) and colchicine (97\%) were from TCI. Nystatin (Biotech grade) was from Biosharp. Monensin (98\%) was from Shanghai Yuanye. bicinchoninic acid kit and Triton X-100 lysate were purchased from Beyotime. Bovine serum albumin (BSA, 98\%) was obtained from Santa Cruz. Penicillin, streptomycin, Roswell Park Memorial Institute medium (RPMI)-1640, fetal bovine serum (FBS), and trypsin were purchased from Hyclone. All other reagents were of analytical grade and were 
used as received unless otherwise specified. Water used in this study was double-distilled water.

\section{Cell lines}

Human hepatoma carcinoma (Huh-7) cells and Chinese hamster lung (CHL) cells were purchased from the Cell Bank of Shanghai Institute of Cell Biology, Chinese Academy of Sciences. The cells were cultured in RPMI-1640 medium, supplemented with $10 \% \mathrm{FBS}, 100 \mathrm{IU} \mathrm{mL}^{-1}$ of penicillin, and $100 \mu \mathrm{g} \mathrm{mL}^{-1}$ of streptomycin sulfate, and maintained under a fully humidified atmosphere with $5 \% \mathrm{CO}_{2}$ at $37^{\circ} \mathrm{C}$. All experiments were performed on cells which were in the logarithmic phase of growth.

\section{Synthesis of PFS}

The $N$-carboxyanhydride (NCA) of L-phenylalanine (PheNCA) was prepared as previously reported. ${ }^{27}$ The NCA of $O$-TBDMS-L-serine ( $O$-TBDMS-Ser-NCA) was synthesized as follows. L-Serine $(2.1 \mathrm{~g})$ was suspended in $30 \mathrm{~mL}$ of anhydrous acetonitrile, and then TBDMSCl (4.5 g) and DBU were added at $0^{\circ} \mathrm{C}$. The mixture was stirred at $0^{\circ} \mathrm{C}$ for 30 minutes and kept at $25^{\circ} \mathrm{C}$ for 24 hours. The suspension was filtered to remove unreacted TBDMSCl, and the filter cake was dissolved in methanol $(5 \mathrm{~mL})$ and filtered again. The methanol solution was dropped into acetonitrile $(50 \mathrm{~mL})$, and the intermediate ( $O$-TBDMS-L-serine) was precipitated from acetonitrile. After filtration and vacuum drying, $O$-TBDMS-L-serine was obtained. $O$-TBDMS-Lserine $(2.2 \mathrm{~g})$ and triphosgene $(2.4 \mathrm{~g})$ were dissolved in anhydrous THF $(20 \mathrm{~mL})$, and the mixture was stirred at $65^{\circ} \mathrm{C}$ with refluxing for 6 hours. The solution was purged with nitrogen until the phosgene was cleared. After vacuum distillation, the resulting oil was dissolved in anhydrous ethyl acetate $(5 \mathrm{~mL})$ and tenfold anhydrous ether was added, and the mixture was kept at $-20^{\circ} \mathrm{C}$ for 2 hours. After separation and vacuum drying, $O$-TBDMS-Ser-NCA was obtained. $O$-TBDMS-Ser-NCA was dissolved in anhydrous dimethylformamide (DMF) and initiated with pyridine under a nitrogen atmosphere. After polymerization at $50^{\circ} \mathrm{C}$ for 12 hours, Phe-NCA was added and the polymerization proceeded at $50^{\circ} \mathrm{C}$ for another 12 hours. The solution was then poured into excess cold ether, causing the polypeptides to precipitate. After filtration, poly(L-phenylalanine)- $b$-( $O$-TBDMS-Lserine) was dissolved in DMF, and TBAF (2 equiv) was added. The reaction mixture was stirred at room temperature for 4 hours to deprotect TBDMS groups. The mixture was dialyzed against several changes of water for 24 hours and followed by filtration and lyophilization. PFS polypeptides were collected as a brown powder.
PFS and RBITC (1 equiv) were dissolved in DMF and kept stirring for 24 hours at room temperature away from light. After adequate dialysis and lyophilization, RBITClabeled PFS polypeptides (RBITC-PFS) were collected as a red powder.

\section{Characterization of PFS}

${ }^{1} \mathrm{H}$ NMR measurements were performed on an AVANCE DMX 500 spectrometer (Bruker, Karlsruhe, Germany). The solvent was dimethyl sulfoxide-d6 (DMSO)- $d 6$ and the internal reference was tetramethylsilane.

FTIR measurements were recorded on a FTIR 8400s spectrometer (Shimadu, Kyoto, Japan) in KBr discs.

CD spectra were measured at 185-250 nm of wavelength, $100 \mathrm{~nm} \mathrm{m^{-1 }}$ rate, on a J-815 spectropolarimeter (Jasco, Tokyo, Japan). PFS samples were dissolved in phosphatebuffered saline (PBS; $50 \mathrm{mM}$, pH 7.4) and 50\% (v/v) aqueous solution of TFE.

\section{Preparation and characterization of PFS micelles}

PFS micelles were prepared using a dialysis method. In brief, lyophilized PFS (100 mg) was dissolved in ethanol $(5 \mathrm{~mL})$, and then dialyzed against several changes of water. After sonication and filtration, PFS micelles suspension was obtained.

The particle size and zeta potential of PFS micelles were determined by a Nicomp 380/ZLS particle size/zeta potential analyzer (Particle Sizing System, Santa Barbara, CA, USA) at a concentration of $2.0 \mathrm{mg} \mathrm{mL}^{-1}$.

The morphology of the PFS micelles was studied by a Tecnai Spirit G2 TWIN transmission electron microscope (FEI, Hillsboro, OR, USA). The PFS micelles suspension (1.0 $\left.\mathrm{mg} \mathrm{mL}^{-1}\right)$ was dropped onto a copper grid and water was allowed to evaporate at room temperature for 12 hours.

The critical micelle concentration (CMC) of PFS micelles was determined by a F4600 fluorescence spectrophotometer (Hitachi, Tokyo, Japan) with pyrene as a hydrophobic probe. The pyrene solution in methanol was added to vials and evaporated to dryness under a nitrogen atmosphere. Then PFS suspensions with different concentrations $\left(1.0 \times 10^{-4}-0.2 \mathrm{mg} \mathrm{mL}^{-1}\right)$ were added, and the final concentration of pyrene was $6.0 \times 10^{-7} \mathrm{M}$. The mixtures were sonicated for 1 hour before measurement. The emission spectra were recorded at an excitation wavelength of $337 \mathrm{~nm}$ with a set of $5 \mathrm{~nm}$ excitation and $5 \mathrm{~nm}$ emission slits. The intensity ratio $\left(I_{373} / I_{384}\right)$ of the emission spectra was plotted against the logarithm of the concentration of PFS, and the CMC value was calculated from the inflection point of the plots. 
The stabilities of PFS micelles in stock solutions and biological fluid were studied by dynamic light scattering (DLS). The following buffer solutions were used: acetate buffer (pH 5, $0.15 \mathrm{M}$ ), phosphate buffer (pH 6 and $\mathrm{pH} 7.4$, $0.15 \mathrm{M}$ ), and borate buffer ( $\mathrm{pH} 9,0.15 \mathrm{M})$. To examine the stability of PFS micelles over time, PFS micelles (PFS2, PFS3, and PFS4) were stored in PBS (pH 7.4, 0.15 M) at room temperature for 8 days, and the micellar diameters were measured at different times. To investigate the stability of micelles under physiological conditions, PFS3 micelles were suspended in a BSA solution $\left(45 \mathrm{mg} \mathrm{mL}^{-1}\right)$ in PBS ( $\mathrm{pH} 7.4,0.15 \mathrm{M}$ ). The suspension was incubated at $37^{\circ} \mathrm{C}$ and $100 \mathrm{rpm}$ for 24 hours and determined at time intervals. PFS3 micelles were suspended in $\mathrm{pH} 5, \mathrm{pH} 6$, $\mathrm{pH} 7.4$, and $\mathrm{pH} 9$ buffers at room temperature with gentle agitation for 2 hours, and the diameters were measured. The final concentration of PFS micelles in each solution was $100 \mu \mathrm{g} \mathrm{mL} L^{-1}$.

\section{Drug loading and in vitro release behavior}

Coumarin-6-loaded PFS micelles were prepared using the dialysis method as follows: coumarin-6 $(10 \mathrm{mg})$ and PFS polypeptides $(200 \mathrm{mg})$ were dissolved in ethanol $(5 \mathrm{~mL})$ and dialyzed against three changes of water for 6 hours. The unentrapped coumarin- 6 was removed by filtration through a $0.45 \mu \mathrm{m}$ membrane and the coumarin-6-loaded PFS micelles were obtained. For comparison, the thin-film dispersion method was used to prepare coumarin-6-loaded PFS micelles. Briefly, coumarin-6 (10 mg) and PFS polypeptides $(200 \mathrm{mg})$ were dissolved in ethanol $(10 \mathrm{~mL})$ in a round-bottomed flask. The organic phase was removed by rotary evaporation under reduced pressure to yield a thin film containing drugs on the wall of flask. The resulting film containing drugs was dispersed by adding $20 \mathrm{~mL}$ of water and sonicated for 30 minutes at room temperature. The mixture was filtered through a $0.45 \mu \mathrm{m}$ membrane to obtain coumarin-6-loaded micelles.

The drug loading capacity (LC) and entrapment efficiency were defined by measuring the amount of coumarin- 6 encapsulated in PFS micelles through the following method. A certain amount of coumarin-6-loaded micelles suspension was diluted ten times with methanol and sonicated for 10 minutes. After centrifugation at $12,000 \mathrm{rpm}$ for 10 minutes, the concentration of coumarin- 6 in the supernatant was detected by the fluorescence spectrophotometer $\left(\lambda_{\mathrm{ex}}=446 \mathrm{~nm}, \lambda_{\mathrm{em}}=507 \mathrm{~nm}\right)$, and the total amount of encapsulated coumarin- 6 was calculated.
In vitro drug release behavior was evaluated using the dialysis method. Coumarin-6-loaded PFS micelles $(1 \mathrm{~mL})$ was taken into a dialysis bag (MWCO 1,000) and dialyzed against $100 \mathrm{~mL}$ of PBS $(0.15 \mathrm{M}, \mathrm{pH} 7.4)$ at $37^{\circ} \mathrm{C}$ and $100 \mathrm{rpm}$. At predefined time intervals, $10 \mathrm{~mL}$ of release medium was collected and fresh PBS of equal volume was added. The samples were diluted ten times with methanol and centrifuged for 10 minutes at 12,000 rpm. The amount of coumarin- 6 in the supernatant was determined by the fluorescence spectrophotometer $\left(\lambda_{\mathrm{ex}}=446 \mathrm{~nm}, \lambda_{\mathrm{em}}=507 \mathrm{~nm}\right)$, and the cumulative released amount was calculated.

\section{Intracellular uptake of drug-loaded PFS micelles}

Huh-7 cells were seeded in 24-well plates at a density of $1 \times 10^{5}$ cells/well and incubated for 24 hours. Before treatment with micelles, the medium was changed to RPMI-1640 without serine and phenylalanine. Coumarin- 6 was loaded into RBITC-PFS micelles as a model drug. To study the effect of concentration on uptake, Huh-7 cells were incubated with coumarin-6-loaded RBITC-PFS micelles at different micellar concentrations $\left(50-1,500 \mu \mathrm{g} \mathrm{mL}^{-1}\right)$ for 2 hours at $37^{\circ} \mathrm{C}$. To study the effect of temperature on uptake, Huh- 7 cells were incubated with $500 \mu \mathrm{g} \mathrm{mL} \mathrm{m}^{-1}$ of coumarin-6-loaded RBITC-PFS micelles for 2 hours at $4^{\circ} \mathrm{C}$. To study the effect of incubation time on uptake, Huh-7 cells were incubated with $500 \mu \mathrm{g} \mathrm{mL}^{-1}$ of coumarin-6-loaded RBITC-PFS micelles for 30 minutes, 1 hour, 2 hours, and 4 hours at $37^{\circ} \mathrm{C}$. After that, the cells were washed with cold PBS (pH 7.4) and visualized under a Leica DMIL LED fluorescent microscope (Leica, Solms, Germany). After observation, the cells were lysed with Triton X-100 lysate, and the cell lysates were centrifuged at 3,000 rpm for 10 minutes. The fluorescence intensities of $\operatorname{RBITC}\left(\lambda_{\mathrm{ex}}=547 \mathrm{~nm}, \lambda_{\mathrm{em}}=582 \mathrm{~nm}\right)$ and coumarin- $6\left(\lambda_{\mathrm{ex}}\right.$ $=446 \mathrm{~nm}, \lambda_{\mathrm{em}}=507 \mathrm{~nm}$ ) in supernatants were determined. Fluorescence intensity was normalized with respect to total protein content. The protein content was determined using bicinchoninic acid protein assay kit according to the method specified by the manufacturer.

\section{Cellular uptake mechanism}

Huh-7 cells were incubated in 24-well plates as mentioned above. Before treatment with micelles and inhibitors, the medium was changed to RPMI-1640 without serine and phenylalanine. Inhibitors including CPZ $\left(10 \mu \mathrm{g} \mathrm{mL}^{-1}\right)$, colchicine $\left(25 \mu \mathrm{g} \mathrm{mL}^{-1}\right), \mathrm{NaN}_{3}\left(1 \mathrm{mg} \mathrm{mL} \mathrm{L}^{-1}\right)$, nystatin $\left(3 \mathrm{mg} \mathrm{mL}^{-1}\right)$, and monensin sodium $\left(2 \mu \mathrm{g} \mathrm{mL}^{-1}\right)$ were co-incubated with tumor cells. In addition to these inhibitors, different 
amounts of serine (final concentration of 20-100 $\mu \mathrm{g} \mathrm{mL}^{-1}$ ) and phenylalanine (final concentration of $20-100 \mu \mathrm{g} \mathrm{mL}^{-1}$ ) were added to reveal whether the uptake was related to the constituents of PFS. All inhibitors and two amino acids were incubated with Huh-7 cells for 30 minutes, and then RBITC-PFS micelles were added (final concentration of $500 \mu \mathrm{g} \mathrm{mL}^{-1}$ ) and incubated for another 2 hours. At the end of the incubation period, the fluorescence intensities of RBITC were determined as described previously.

\section{In vitro tumor targeting of PFS micelles}

CHL cells were seeded in 24-well plates at a density of $5 \times 10^{4}$ cells/well and incubated for 24 hours. Before treatment with micelles, the medium was changed to RPMI-1640 without serine and phenylalanine. Then, CHL cells were incubated with RBITC-PFS micelles at different concentrations $\left(50-1,500 \mu \mathrm{g} \mathrm{mL}^{-1}\right)$ for 2 hours at $37^{\circ} \mathrm{C}$. In addition, the effect of free serine (final concentration of $20-100 \mu \mathrm{g} \mathrm{mL}^{-1}$ ) was also investigated in CHL cells. Observations by fluorescent microscope and fluorescence measurements of RBITC were conducted according to the above-mentioned steps.

\section{Statistical analysis}

Student's two-sample $t$-test was utilized for statistical analysis. In all cases, $P<0.05$ was considered as significant, $P<0.01$ highly significant, and $P<0.001$ very highly significant, which was noted in figures and tables with asterisks.

\section{Results and discussion Synthesis of PFS}

Ring-opening polymerization of NCA is a general method for the preparation of polyamino acids. ${ }^{28}$ Poly(L-serine) has been synthesized using the NCA method through different routes. One way was the direct polymerization of L-serine-NCA. ${ }^{29}$ In another way, hydroxyl-protected serine NCA, such as $O$-acetyl-L-serine-NCA or $O$-tert-butyl-L-serine-NCA, was synthesized as the monomer of polymerization, and deprotection was followed to get the desired poly(L-serine). ${ }^{29,30}$ Poly(L-serine) derivatives with elongated side chains were prepared using the NCA method as functional materials, too. ${ }^{31} \mathrm{We}$ found that serine was practically insoluble in most organic solvents and got stuck on the flask as the reaction with phosgene went on, thus making the reaction incomplete. Therefore, the direct polymerization of serine-NCA might not be the best way. In this study, we made some changes on the traditional synthetic method. First, TBDMS was used as the protecting group of hydroxyl instead of acetyl or tertbutyl. In the cases of using DBU as the catalyst, L-serine was found to react well with TBDMSCl in acetonitrile. The middle product, $O$-TBDMS-L-serine, gained improvement in solubility and could dissolve in some organic solvents, such as THF and methanol. $O$-TBDMS-L-serine reacted well with triphosgene in anhydrous THF and the yield of $O$-TBDMSSer-NCA could be increased to nearly $100 \%$. After polymerization, the TBDMS groups of the polypeptides could be easily deprotected by treatment with TBAF under a mild condition that did not destroy the resulting polypeptides.

\section{Characterization of PFS}

The FTIR spectrum of PFS is shown in Figure 1A. infrared $(\mathrm{KBr})\left(v, \mathrm{~cm}^{-1}\right): 3,398(\mathrm{OH} \mathrm{st}), 3,205$ (NH st), 3,032 (Ar C-H st), 2,928 ( $\mathrm{CH}_{2} \mathrm{st}$ ), 2,880 (CH st), 1,676, 1,660 (CO st, amide I), 1,605, 1,497, 1,460 (Ar C=C st), 1,330, 1,265 (amide III), $1,092(\mathrm{C}-\mathrm{O}$ st), $758(\mathrm{Ar} \mathrm{C}-\mathrm{H} \delta), 700(\mathrm{Ar} \mathrm{C}-\mathrm{H} \delta)$. The broad
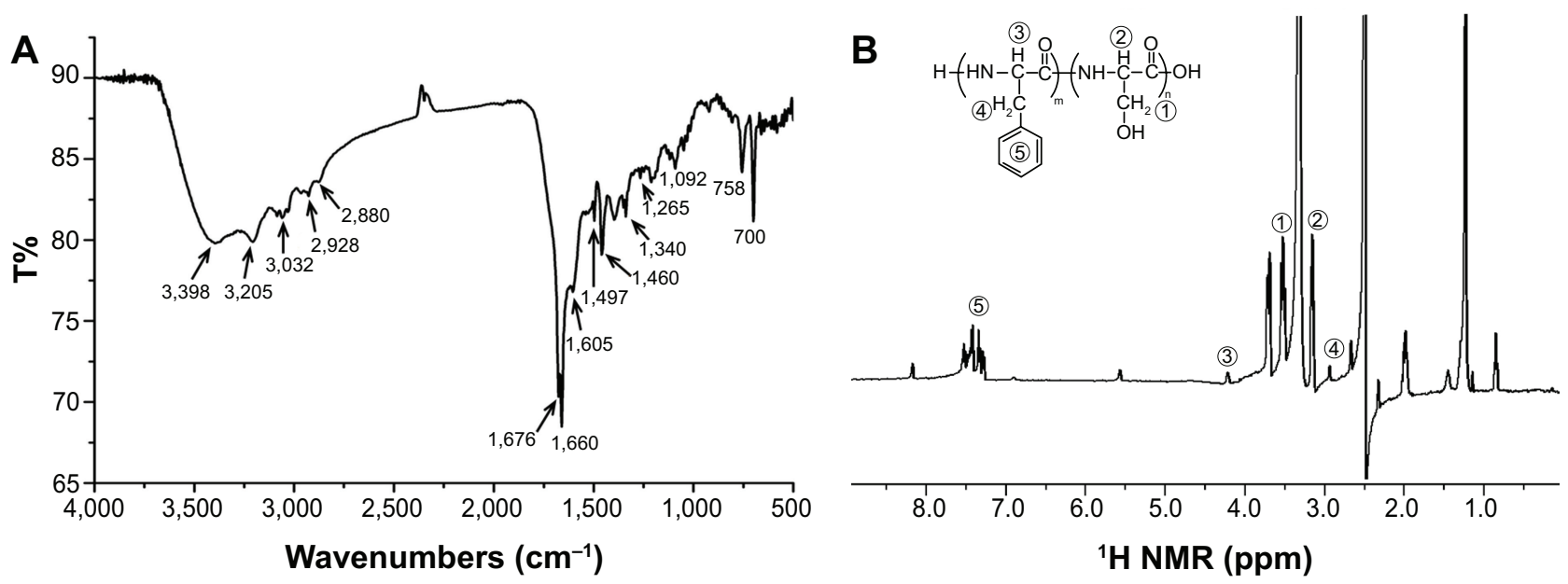

Figure I IR spectrum and 'H NMR spectrum of PFS.

Notes: (A) IR spectrum of PFS. (B) 'H NMR spectrum of PFS in DMSO-d6; I-5 show hydrogen in different positions.

Abbreviation: DMSO, dimethyl sulfoxide; IR, infrared; NMR, nuclear magnetic resonance; PFS, poly(L-phenylalanine)-b-poly(L-serine); Ppm, parts per million. 
peak at $3,398 \mathrm{~cm}^{-1}$ attributed to $\mathrm{O}-\mathrm{H}$ stretch of hydrogenbonded hydroxyls and the peak at $1,092 \mathrm{~cm}^{-1}$ belonging to C-O stretch of hydroxyls suggested the presence of serine residues. The peaks at $3,032 \mathrm{~cm}^{-1}, 1,605 \mathrm{~cm}^{-1}, 1,497 \mathrm{~cm}^{-1}$, $1,460 \mathrm{~cm}^{-1}, 758 \mathrm{~cm}^{-1}$, and $700 \mathrm{~cm}^{-1}$ were attributed to $\mathrm{C}-\mathrm{H}$ stretch, $\mathrm{C}=\mathrm{C}$ stretch, and $\mathrm{C}-\mathrm{H}$ bend of benzenes, which indicated the existence of phenylalanine residues.

The molecular structure of PFS was verified by ${ }^{1} \mathrm{H}$ NMR (Figure 1B). ${ }^{1} \mathrm{H}$ NMR (500 MHz, DMSO-d6): $\delta=7.58-7.23$ (m, $\mathrm{ArH}), 4.17$ (s, $\left.\mathrm{CHCH}_{2} \mathrm{Ph}\right), 3.53$ (m, $\mathrm{CHCH}_{2} \mathrm{O}-$ ), 3.16 (m, $\left.\mathrm{CHCH}_{2} \mathrm{O}-\right), 2.94\left(\mathrm{~s},-\mathrm{CH}_{2} \mathrm{Ph}\right) .{ }^{31,32}$ The molar ratio of serine to phenylalanine $(\mathrm{S} / \mathrm{F})$ was calculated by comparing the ratio of methene protons $(\delta=3.53 \mathrm{ppm})$ to benzene protons $(\delta=7.23-7.58 \mathrm{ppm})$.

The CD spectrum of PFS dissolved in PBS $(50 \mathrm{mM}$, $\mathrm{pH}$ 7.4) exhibited a negative band at $198 \mathrm{~nm}$ and a positive band at $210 \mathrm{~nm}$, which represented the characteristic of random coil (Figure 2A). Doruker et al have reported that poly(L-serine) exhibits $\alpha$-helix conformation in water and the helix can transform to random coil. The critical factor of maintaining $\alpha$-helix conformation of poly(L-serine) is that most side hydroxyls form hydrogen bonds with water molecules rather than the carbonyls on the backbone. If the hydrogen bonds between hydroxyls and backbone increase, the $\alpha$-helix will unwind. ${ }^{33}$ In our study, PFS polypeptides formed micelles at the detection concentration of CD (0.1 $\left.\mathrm{mg} \mathrm{mL}^{-1}\right)$, causing the aggregation of poly(L-serine) chains. As a result, more complicated intermolecular hydrogen bonds between the neighboring poly(L-serine) chains formed, which disturbed the intramolecular hydrogen bonds between carbonyls and amidos and led to the helix-coil transition. To study the original secondary structure of dispersive PFS polypeptide, $50 \%$ (v/v) aqueous solution of TFE was

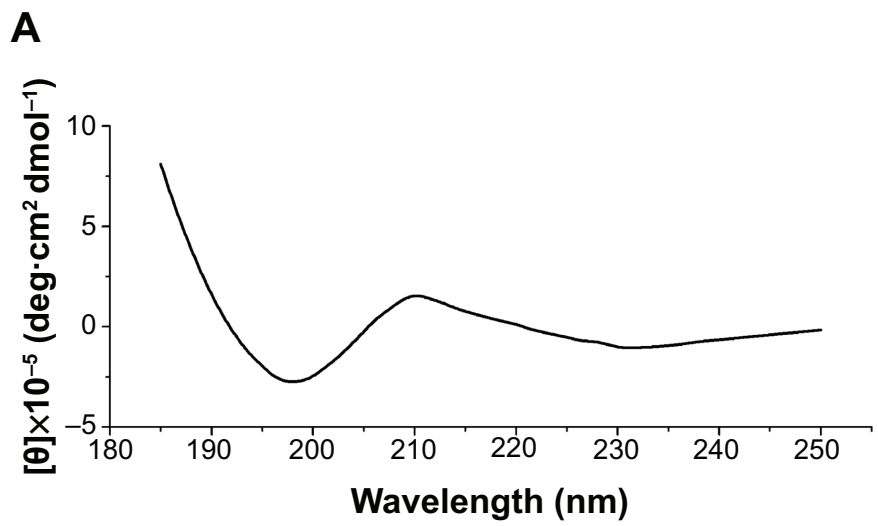

used as a solvent. TFE can disassemble micellar structure by destroying the hydrophobic interaction and can induce the formation of secondary structures of polypeptides. ${ }^{34}$ As shown in Figure 2B, PFS in 50\% TFE solution displayed a strong positive band at $192 \mathrm{~nm}$ and two weak positive bands at $205 \mathrm{~nm}$ and $216 \mathrm{~nm}$. It also had a main negative band at $197 \mathrm{~nm}$ and two weak negative bands at $210 \mathrm{~nm}$ and $222 \mathrm{~nm}$. The spectrum indicated that dispersive PFS reconstructed $\alpha$-helix in the presence of TFE, and there still remained part of random coils in the conformation. ${ }^{35}$

\section{Characterization of PFS micelles}

The length ratio of the hydrophilic to hydrophobic domains is an important factor that determines whether block polymers can self-assemble into micelles in water and the morphology of micelles. ${ }^{36}$ Holowka et al prepared and studied a series of poly(L-lysine)- $b$-poly(L-leucine) block copolypeptides, $\mathrm{K}_{x} \mathrm{~L}_{y}$. They found that samples with high $\mathrm{K} / \mathrm{L}$ molar ratios (eg, $\mathrm{K}_{180} \mathrm{~L}_{20}$ ) could dissolve directly in water and samples containing lower $\mathrm{K} / \mathrm{L}$ ratios formed ill-defined aggregates with large particle size. Poly(L-lysine)- $b$-poly(L-leucine) polypeptides with K/L molar ratio of 3-6 were found to have nanoscale. The PFS polypeptides with various $\mathrm{S} / \mathrm{F}$ molar ratios were prepared and their solubilities and self-assembly abilities were studied. We found that samples with lower $\mathrm{S} / \mathrm{F}$ molar ratio $(S / F<2)$ were hardly soluble in water. When the $S / F$ molar ratio was higher than 4 , the PFS polypeptides dissolved readily in water, but they could not form aggregates. As the $\mathrm{S} / \mathrm{F}$ molar ratio ranged from 2 to 4 , the PFS polypeptides were able to self-assemble into micelles in water.

Particle size is an important factor that effects the accumulation and endocytosis of nanocarriers. Generally, nanoparticles with a diameter of approximately 50-200 nm

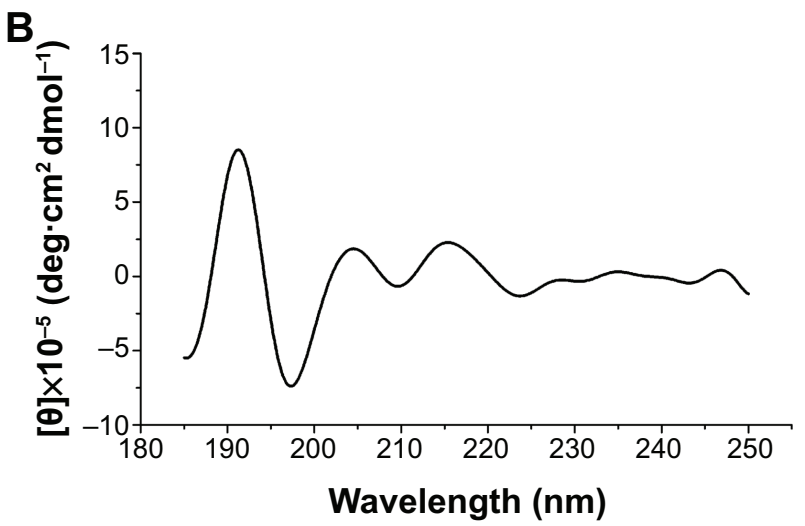

Figure 2 CD spectrum of PFS3.

Notes: (A) CD spectrum of PFS3 in phosphate-buffered saline $(50 \mathrm{mM}, \mathrm{pH} 7.4)$. (B) CD spectrum of PFS3 in $50 \%$ (v/v) aqueous solution of trifluoroethanol. Abbreviations: $C D$, circular dichroism; PFS, poly(L-phenylalanine)-b-poly(L-serine); v/v, volume ratio; $\theta$, mean residual ellipticity. 
Table I Particle size, zeta potential, and constituent of PFS micelles

\begin{tabular}{lllll}
\hline Copolypeptide & Size $(\mathbf{n m})($ mean \pm SD) & PDI $^{\text {a }}$ & Zeta potential $(\mathbf{m V})(\mathbf{m e a n} \pm$ SD) & Found composition $^{\mathbf{b}}$ \\
\hline PFSI $\left(F_{5} S_{5}\right)$ & $2,150 \pm 390$ & 0.38 & $-5.7 \pm 1.3$ & $F_{4} S_{5}$ \\
PFS2 $\left(F_{5} S_{10}\right)$ & $109 \pm 16$ & 0.18 & $-3.8 \pm 1.4$ & $F_{5} S_{9}$ \\
PFS3 $\left(F_{5} S_{20}\right)$ & $155 \pm 22$ & 0.14 & $-4.3 \pm 1.8$ & $F_{5} S_{17}$ \\
PFS4 $\left(F_{10} S_{20}\right)$ & $239 \pm 41$ & 0.23 & $-2.6 \pm 0.9$ & $F_{8} S_{16}$ \\
\hline
\end{tabular}

Notes: assembly polydispersities were determined using dynamic light scattering. ${ }^{b}$ Found compositions were determined using MALDI-TOF-MS and 'H NMR.

Abbreviations: SD, standard deviation; PDI, polydispersity index; PFS, poly(L-phenylalanine)-b-poly(L-serine); NMR, nucelar magnetic resonance; MALDI-TOF-MS, matrixassisted laser desorption/ionization time of flight mass spectrometry.

are regarded as favorable to deliver drugs into tumors. ${ }^{37} \mathrm{In}$ this study, PFS (PFS2-PFS4) micelles determined by DLS have an average diameter of around 110-240 nm with a good polydispersity index $(<0.25)$ (Table 1$)$. The size of PFS micelles is mainly affected by the $\mathrm{S} / \mathrm{F}$ molar ratio and their relative molecular weights. When the oligophenylalanine domain was held constant at five residues, the particle size increased with the S/F molar ratio, possibly because the longer poly(L-serine) chains thickened the hydrophilic shell and the hydration layer. If the $\mathrm{S} / \mathrm{F}$ molar ratio was fixed at 2 , the particle size increased with the molecular weight of PFS. Considering the recommended particle size, PFS2 and PFS3 are more suitable for antitumor drug delivery.

As shown in Table 1, the zeta potential of PFS micelles is slightly negative at -2 to $-5 \mathrm{mV}$ under neutral condition. Since there are no ionizable side groups in PFS, the slight negative charges are owing to the terminal carboxyls of the polypeptides. The zeta potential of colloidal systems exerts a major effect on the circulation time in blood. Particles with too high negative or positive charges tend to be rapidly opsonized and massively cleared by macrophages of MPS, and the biodistribution results suggest that particles with slight negative charges are favorable to accumulate in tumor more efficiently. ${ }^{38}$ Therefore, the surface charge of PFS is an advantage for tumor targeting delivery.

As shown in Figure 3, PFS micelles have nearly spherical shapes with a core-shell structure and a narrow diameter distribution. The hydrophilic layer that consists of poly(L-serine) segment has cloud-like appearance and irregular boundary. The particle size, as estimated by transmission electron microscope (TEM), was smaller than the size measured with DLS. It is known that DLS measures the hydrodynamic diameter of the core of particle along with any coating materials and the solvation layer attached to the particle. It is more accurate for soft materials, such as proteins. ${ }^{39}$ When PFS polypeptides were dispersed in water, the hydrophilic poly(L-serine) chains formed a thick hydration layer outside the micelles. However, this hydration layer was not present under TEM after sample preparation. ${ }^{40}$ Hence, the hydrodynamic diameter of PFS was larger than the size estimated by TEM.
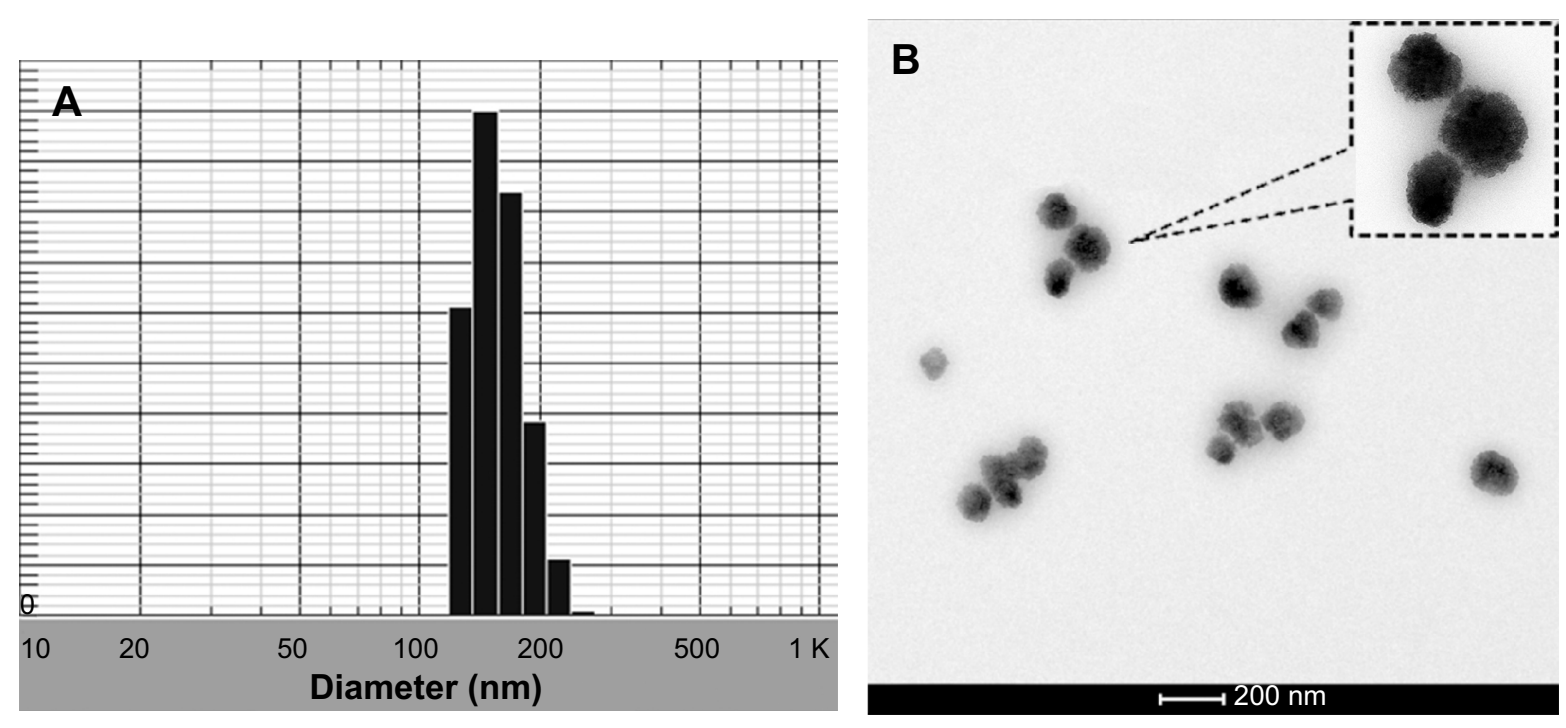

Figure 3 DLS and TEM images of PFS3.

Notes: (A) Size distribution of PFS3 micelles determined by dynamic light scattering; (B) TEM image of PFS3 micelles at a concentration of $1.0 \mathrm{mg}^{-1} \mathrm{~mL}^{-1}$. Abbreviation: DLS, dynamic light scattering; PFS, poly(L-phenylalanine)-b-poly(L-serine); TEM, transmission electron microscope. 
The stability of PFS micelles in stock solutions and biological fluid was investigated by monitoring the variation of particle size. When stored in PBS at room temperature, the particle size of PFS3 micelles did not vary during 8 days, thus proving their stabilities in the typical stock media. PFS4 micelles were basically stable with a little increase in size after 8 days, while PFS2 aggregated and precipitated quickly (Figure 4A). The main factors that maintain the stability of colloidal systems are electrostatic repulsion caused by surface charges and steric hindrance caused by hydration layer. Generally, colloid particles are stable when the absolute value of their zeta potential exceeds $20 \mathrm{mV} .{ }^{41}$ Although possessing weak negative charges, PFS micelles still have good stability, owing primarily to the hydrophilic poly(L-serine) segments. The hydration layer formed by poly(L-serine) segments can provide a dynamic and flexible protective layer outside the micelles and prevent the aggregation between the micelles. Combining with particle size and stability, PFS3 micelle was considered to be an ideal drug carrier and continued to be applied in the rest of this study.

A solution of BSA ( $\left.45 \mathrm{mg} \mathrm{mL}^{-1}\right)$ in PBS (0.15 M, pH 7.4), which was similar to the concentration found in plasma, was prepared to mimic biological fluid..$^{42}$ If micelle size increases in biological fluid in a short time, it means that the plasma proteins are easy to adsorb on the micellar surfaces or the micelles tend to aggregate in blood. In either case, it would lead to the opsonization and uptake by macrophages of MPS and reduce the circulation time of micelles in blood. ${ }^{43}$ As shown in Figure 4B, PFS3 micelles in biological fluid remained stable within 8 hours, and then had a $50 \%$ increase in size from 8 hours to 24 hours. This result indicated that the hydrophilic poly(L-serine) chains could delay the adsorption of albumin on PFS micelles but could not prevent it completely. In spite of this, the stable time of 8 hours was long enough to fit tumor-targeting requirements. Therefore, PFS3 micelles might be suitable for intravenous administration and targeted delivery strategies.
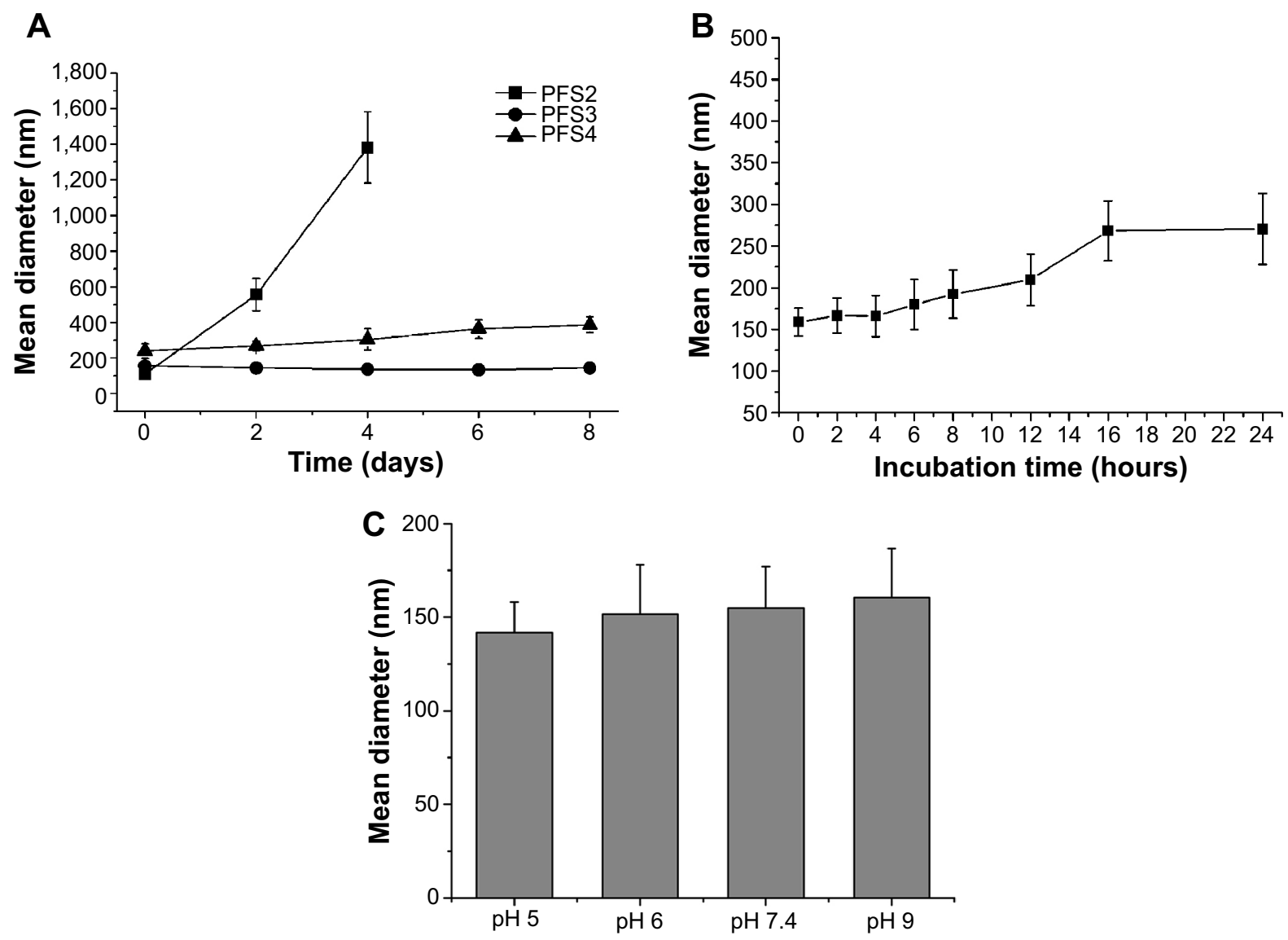

Figure 4 Stability of PFS micelles in stock solutions and biological fluid.

Notes: (A) Changes in micelle size of PFS2, PFS3, and PFS4 in PBS stock solution (0.15 M, pH 7.4) at room temperature. (B) Changes in micelle size of PFS3 in PBS (0.15 M, $\mathrm{pH}$ 7.4) that contains $45 \mathrm{mg} \mathrm{mL}^{-1}$ of bovine serum albumin at $37^{\circ} \mathrm{C}$ and $100 \mathrm{rpm}$. (C) Effects of $\mathrm{pH}$ on the size of PFS3 micelles. The mean diameters of micelles were determined by dynamic light scattering.

Abbreviations: PFS, poly(L-phenylalanine)-b-poly(L-serine); PBS, phosphate-buffered saline. 
The size of PFS3 micelles at various $\mathrm{pH}$ values range from $142 \mathrm{~nm}$ to $161 \mathrm{~nm}$ (Figure 4C). There were no significant changes in size at various $\mathrm{pH}$ values compared with that of poly(L-glutamic acid)- $b$-poly-(L-phenylalanine) and poly(L-lysine)- $b$-poly(L-phenylalanine) ${ }^{27,44}$ which could be explained by the fact that the hydrophilicity of the nonionic poly(L-serine) was not affected by $\mathrm{pH}$. The $\mathrm{pH}$ stability of PFS micelles may be favorable to avoid the degradation of the loaded drugs during transportation in body.

To confirm the formation of micelles, the CMC value of PFS was measured by fluorescence spectroscopy based on selective partition of fluorescence probe in hydrophobic phase against aqueous phase. The fluorescence spectrum of pyrene exhibits five predominant peaks, and the intensity ratio of the first peak $\left(I_{1}\right.$ at $\left.373 \mathrm{~nm}\right)$ to the third peak $\left(I_{3}\right.$ at $384 \mathrm{~nm}$ ) can reflect the polarity of the probe's environment. ${ }^{45}$ The ratios of $I_{373}$ to $I_{384}$ were plotted against the logarithm of the concentration of PFS. As shown in Figure 5A, the CMC value of PFS3 was about $4.0 \mu \mathrm{g} \mathrm{mL} L^{-1}$. Similar to many reported amphiphilic polypeptides, ${ }^{35,43}$ the CMC of PFS is on the order of $10^{-6} \mathrm{M}$, whereas the $\mathrm{CMC}$ for low molecular weight surfactants is on the order of $10^{-3}-10^{-4} \mathrm{M}$. PFS micelles with lower $\mathrm{CMC}$ have a better chance of staying in a micellar form under diluting condition of the systemic circulation in body. ${ }^{46}$

Coumarin-6 is commonly used as a model hydrophobic drug for study, involving drug release, tracking of endocytosis, and intracellular distribution. ${ }^{47}$ The solubility of coumarin-6 in water is $0.25 \mu \mathrm{g} \mathrm{mL}^{-1}$, which makes it suitable as a model for hydrophobic drug, such as paclitaxel. Two methods commonly employed for loading drugs into micelles, the dialysis method and the thin-film dispersion method, were compared. Lavasanifar et al prepared amphotericin B-loaded PEO- $b$-poly $(N$-hexyl stearate L-aspartamide) micelles and found that the encapsulation of drugs using the thin-film dispersion method was slightly better than dialysis. ${ }^{48}$ In our study, the drug LC of the dialysis method was $3.8 \%$, which was higher than that of the thin-film dispersion method (1.3\%). The entrapment efficiency of the dialysis method was $85.1 \%$, which was also better than that of the thin-film dispersion method. Therefore, coumarin-6-loaded micelles were prepared by the dialysis method.

In vitro drug release was conducted in PBS $(0.15 \mathrm{M}, \mathrm{pH} 7.4)$ at $37^{\circ} \mathrm{C}$, and the drug release profile followed a biphasic pattern as shown in Figure 5B. A rapid release was observed during the initial phase (27.6\% within initial 1 hour), which could be contributed to that the drugs adsorbed on the surface of micelles or intercalated between hydrophilic chains were easy to spread into the release medium. After some more time, the drugs entrapped inside the micelles migrated from the hydrophobic core to the surface and then got released slowly into PBS. Approximately $70 \%$ of coumarin- 6 was released from PFS micelles within 24 hours and the sustained release continued for a longer time. Similar release pattern from polymeric micelles was reported in some other studies. ${ }^{49,50}$

\section{Uptake characteristic of coumarin-6- loaded PFS micelles by Huh-7 cells}

Huh-7, a kind of human hepatoma carcinoma cell, was used as the tumor cell model to study the characteristics and mechanisms of uptake of drug-loaded PFS micelles. RBITC was conjugated to PFS by covalent bonds, so that the red
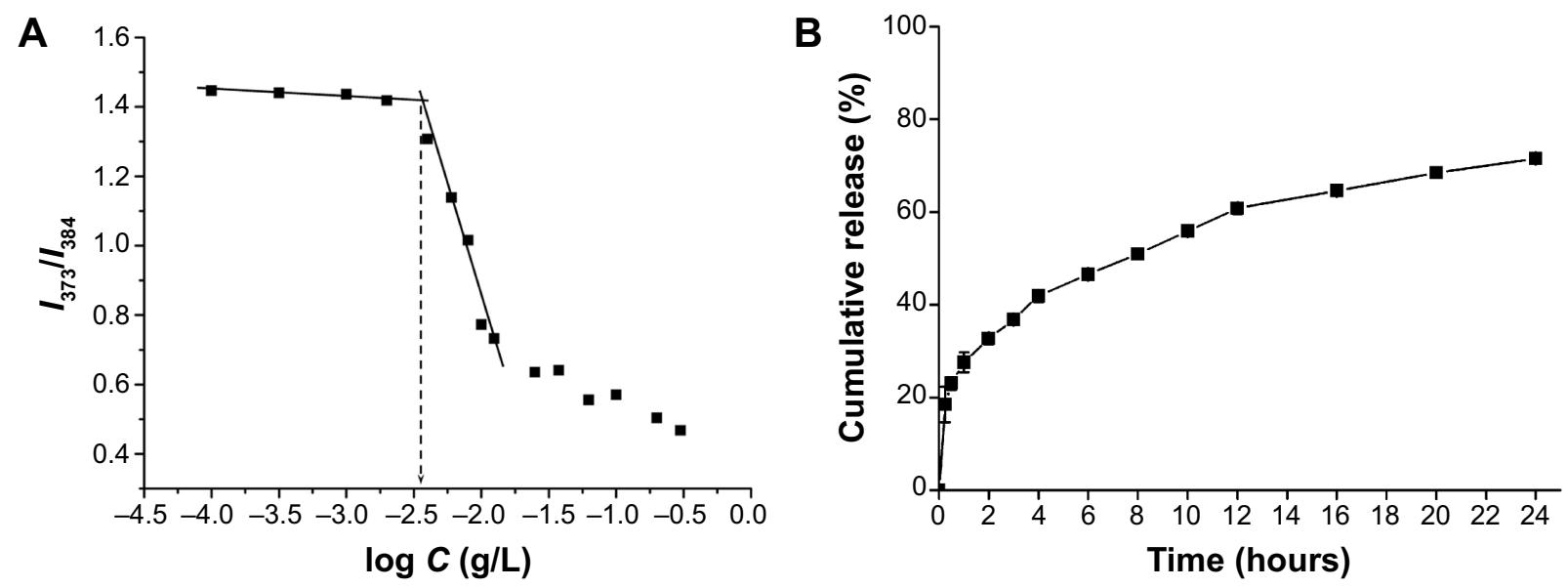

Figure $5 \mathrm{CMC}$ and in vitro drug release of PFS3 micelles.

Notes: (A) Plots of intensity ratio $\left(I_{373} / I_{384}\right)$ from emission spectra versus log C of PFS3 polypeptides. (B) In vitro drug release profiles of coumarin-6 from PFS3 micelles in phosphate-buffered saline $(0.15 \mathrm{M}, \mathrm{pH} 7.4)$ at $37^{\circ} \mathrm{C}$ (mean $\pm \mathrm{SD}, \mathrm{n}=3$ ).

Abbreviations: CMC, critical micelle concentration; PFS, poly(L-phenylalanine)-b-poly(L-serine); SD, standard deviation. 

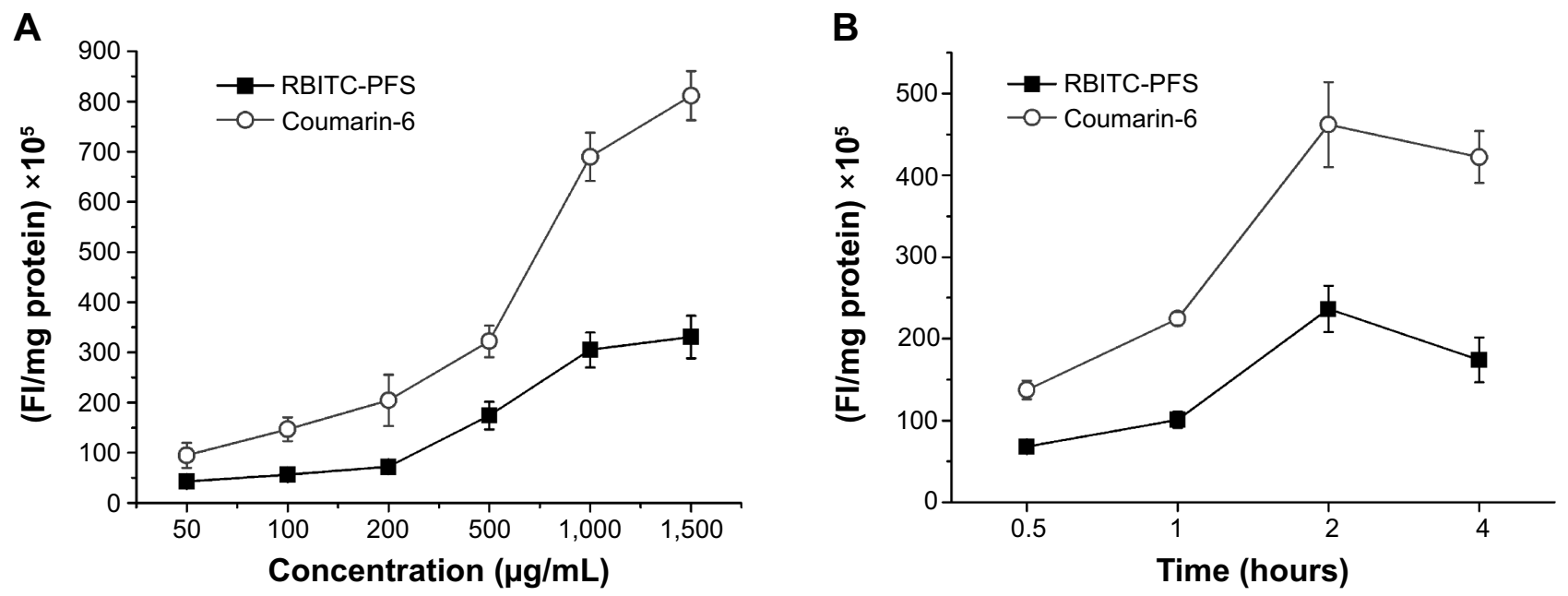

Figure 6 Uptake characteristic of coumarin-6-loaded PFS3 micelles by Huh-7 cells.

Notes: (A) Concentration-dependent uptake of coumarin-6-loaded RBITC-PFS3 micelles by Huh-7 cells. (B) Time-dependent uptake of coumarin-6-loaded RBITC-PFS3 micelles by Huh-7 cells.

Abbreviations: RBITC, rhodamine B isothiocyanate; PFS, poly(L-phenylalanine)-b-poly(L-serine).

fluorescence detected in cells dominantly represented PFS micelles. Coumarin- 6 was encapsulated in the micelles as a model drug, so that the green fluorescence represented drugs. These two types of fluorescent markers were used at the same time to reveal the correlation between micelles and drugs during the internalization process and their intracellular distribution.

The uptake of RBITC-PFS micelles was apparently concentration dependent in the range of $50-1,500 \mu \mathrm{g} \mathrm{mL}$. Increasing the micellar concentration resulted in an increased uptake of PFS micelles (Figure 6A). When the micellar concentration exceeded $1,000 \mu \mathrm{g} \mathrm{mL}{ }^{-1}$, the uptake by Huh-7 cell was close to saturation. As shown in Figure 6B, the uptake of micelles increased with the incubation time within 2 hours, but the fluorescent intensity at 4 hours was weaker than that at 2 hours. These results indicated that the uptake of micelles by Huh- 7 cells was time dependent and nearly complete at 2 hours. As time extended, some of RBITC-PFS in cells might be degraded or quenched, leading to a decrease of the fluorescent intensity. The trend of intracellular fluorescence intensity of coumarin-6 was consistent with the micelles, which illustrated that the transport of the loaded drugs into tumor cells highly depended on the PFS micelles.

The fluorescent images of the internalization process and the intracellular distribution of coumarin-6-loaded PFS micelles are shown in Figure 7, wherein the region glowing yellow meant the micelles and the drugs coincided with each other in these areas. The intracellular distribution of PFS micelles included but not limited to lysosome, and the red fluorescence could be observed in almost the whole cytoplasm. Unlike the micelles, the drugs tended to concentrate in some localized areas. This phenomenon could be contributed to that the micelles were disturbed or disassembled in cells due to the interaction with cellular contents and some particular microenvironments, leading to a burst release of the loaded drugs. Because of insolubility, the released coumarin- 6 was hard to diffuse to other places and be located in the releasing area.

\section{Uptake mechanism of PFS micelles by Huh-7 cells}

To elucidate the uptake mechanism of PFS micelles by Huh-7 cells, the effects of adenosine triphosphate depletion and endocytosis inhibitors on cellular uptake were evaluated quantitatively (Figure 8).

When the cells were pretreated with sodium azide, an adenosine triphosphate-depleting agent, the cellular uptake of PFS micelles decreased significantly, indicating that the internalization of PFS by Huh-7 cells was energy dependent. The influence of temperature on the internalization of PFS micelles was also studied. The uptake of PFS micelles under $37^{\circ} \mathrm{C}$ was much greater than that under $4^{\circ} \mathrm{C}$, suggesting that the uptake of PFS micelles was temperature dependent. The energy- and temperature-dependent internalization of PFS micelles indicated that it was a process of active endocytosis.

Endocytosis, which occurs in most cells as pinocytosis, has at least four basic mechanisms: clathrin-mediated endocytosis, caveolae-mediated endocytosis, macropinocytosis, and clathrin- and caveolae-independent endocytosis. ${ }^{51} \mathrm{We}$ 


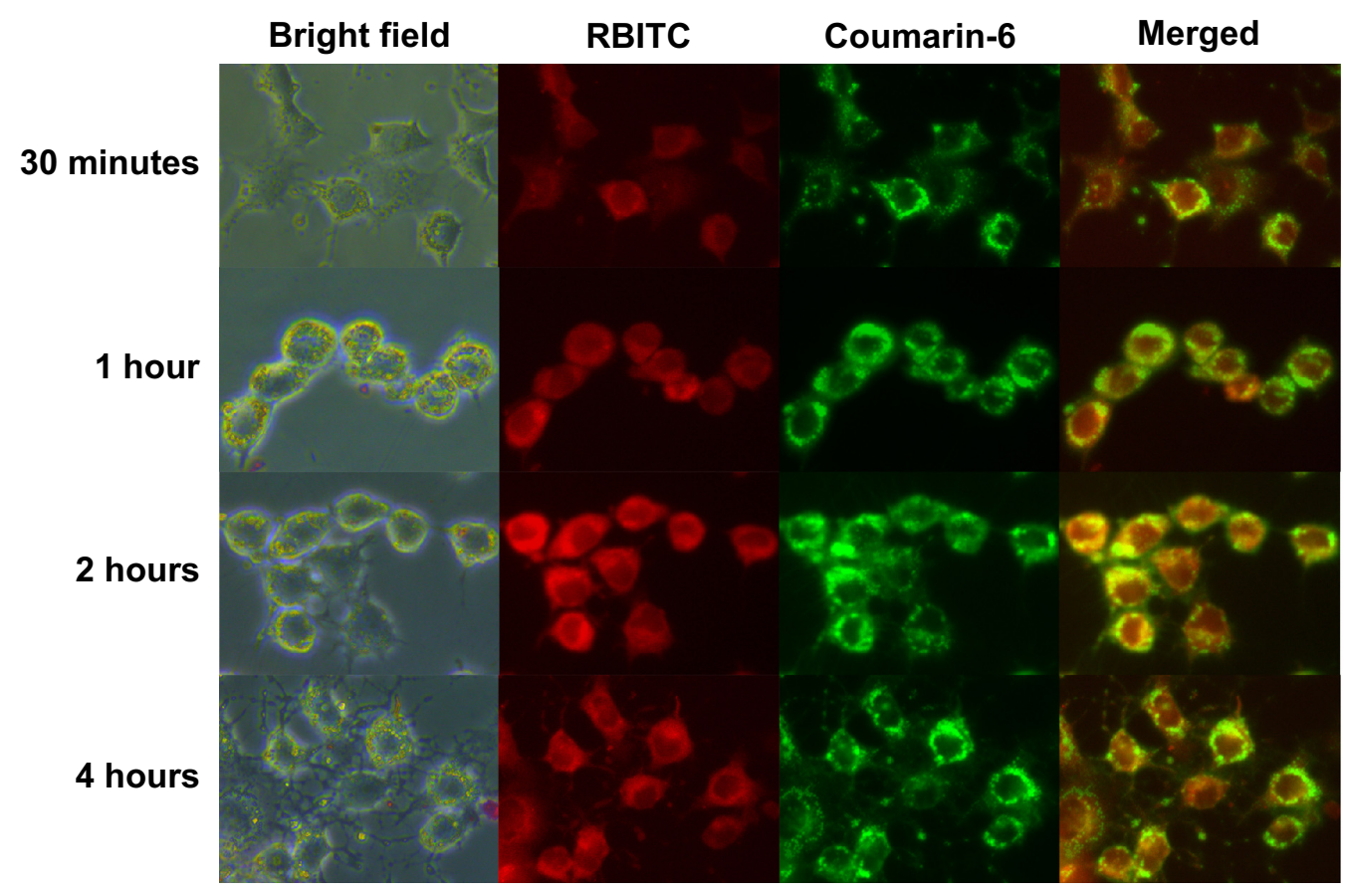

Figure 7 Fluorescence micrographs of the internalization of coumarin-6-loaded RBITC-PFS3 micelles.

Notes: Fluorescence micrographs of Huh-7 cells incubated with coumarin-6-loaded RBITC-PFS3 micelles for 30 minutes, I hour, 2 hours, and 4 hours at $37^{\circ} \mathrm{C}$ (red fluorescence: RBITC; green fluorescence: coumarin-6).

Abbreviations: RBITC, rhodamine B isothiocyanate; PFS, poly(L-phenylalanine)-b-poly(L-serine).

examined the possibility that clathrin-mediated endocytosis contributed to the internalization of PFS micelles into Huh-7 cells. CPZ that blocked clathrin-coated pits formation and monensin that interrupted the recycling of receptors back to the cell surface were used as the inhibitors of clathrinmediated endocytosis. Nystatin, an agent disrupting caveolae,

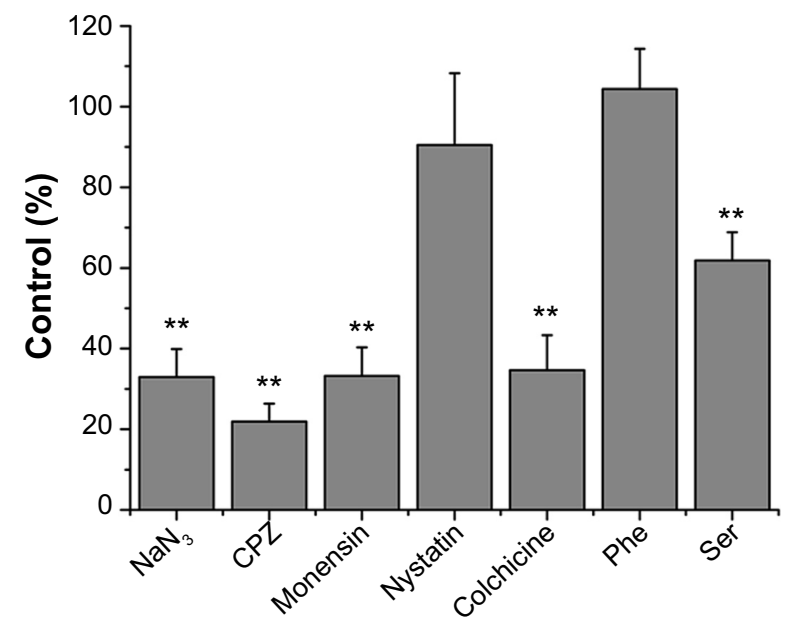

Figure 8 Effects of inhibitors on the uptake of RBITC-PFS3 micelles by Huh-7 cells.

Notes: The fluorescence intensity of RBITC in untreated cells, representing the maximum internalized amount of RBITC-PFS micelles, was taken as control. $* * p<0.0$ l, compared with control $(n=3)$.

Abbreviations: RBITC, rhodamine B isothiocyanate; PFS, poly(L-phenylalanine)-bpoly(L-serine); CPZ, chlorpromazine hydrochloride; Phe, phenylalanine; Ser, serine. was used to evaluate the effects of caveolae-mediated endocytosis on the internalization of the PFS micelles. The contribution of macropinocytosis to the internalization of PFS micelles into Huh-7 cells was confirmed by treating the cells with colchicine, a microtubule-disrupting agent. The adding of CPZ and monensin significantly reduced the uptake of PFS micelles by Huh-7 cells, which indicated that at least a part of PFS micelles were uptaken by cells via clathrin-mediated endocytosis. Adding nystatin had no significant effect on the uptake of PFS micelles, which illustrated that caveolaemediated endocytosis was not the main endocytic pathway of PFS. It has been reported that particles with a diameter below $200 \mathrm{~nm}$ enter the cells via clathrin-mediated endocytosis, whereas larger particles $(200 \mathrm{~nm}-1 \mu \mathrm{m})$ enter mainly via caveolae-mediated endocytosis. ${ }^{52}$ The uptake route of PFS micelles with the average size of about $150 \mathrm{~nm}$ was in agreement with this conclusion. The distinct inhibiting effect of colchicine demonstrated that macropinocytosis was also involved in the uptake of PFS micelles. Macropinocytosis represents an important route of nutrient uptake in tumors and is used to transport extracellular proteins into tumor cells. The internalized proteins undergo proteolytic degradation, yielding amino acids to fulfill the unique metabolic needs of tumors. ${ }^{53}$ PFS polypeptides might be uptaken through 
the micropinocytosis route to support the need for serine of tumor cells.

The rapid growth and reproduction of tumor cells need a lot of serine, and many tumor cells cannot produce serine by themselves. ${ }^{24}$ Receptors of serine, such as L-type amino acid transporter 1 and alanine-serine-cysteine transporter 2, are over-expressed in many types of tumor cells. ${ }^{25,26}$ Therefore, we expected that the interaction of poly(L-serine) and serine receptors could help to increase the uptake of PFS by tumor cells. To confirm this, free serine was preincubated with Huh-7 cells for 30 minutes to competitively bind to the receptors of serine (Figure 9B). When the concentration of serine was similar to the normal level in humans $\left(20 \mu \mathrm{g} \mathrm{mL}^{-1}\right)$, the uptake of PFS micelles was not suppressed significantly. As the concentration of serine increased to $100 \mu \mathrm{g} \mathrm{mL}^{-1}$, the uptake of PFS micelles reduced by $40 \%$. These results indicated that the receptors of serine did play a positive role in the uptake of PFS micelles by tumor cells, and this promoting effect was not inhibited by physiological concentration of serine. Free phenylalanine was also preincubated with Huh-7 cells to evaluate its effect on the uptake. The result showed that phenylalanine had no effect on the uptake of PFS micelles

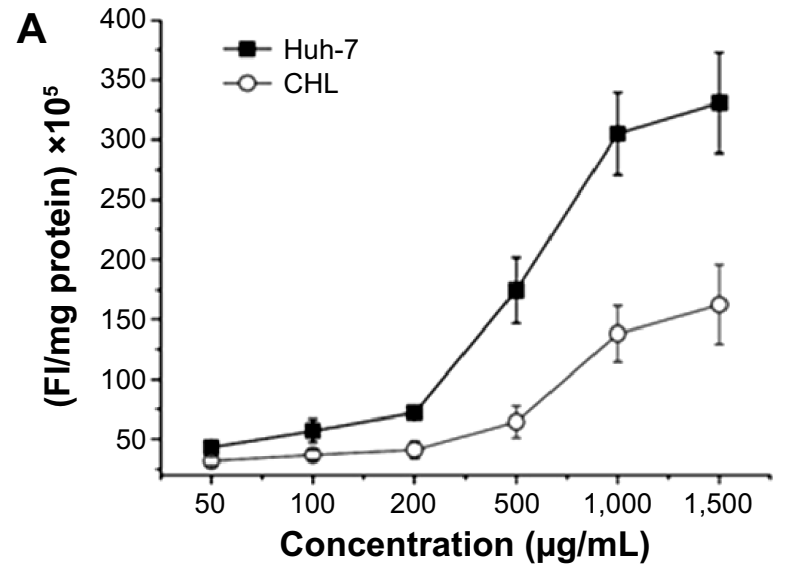

C

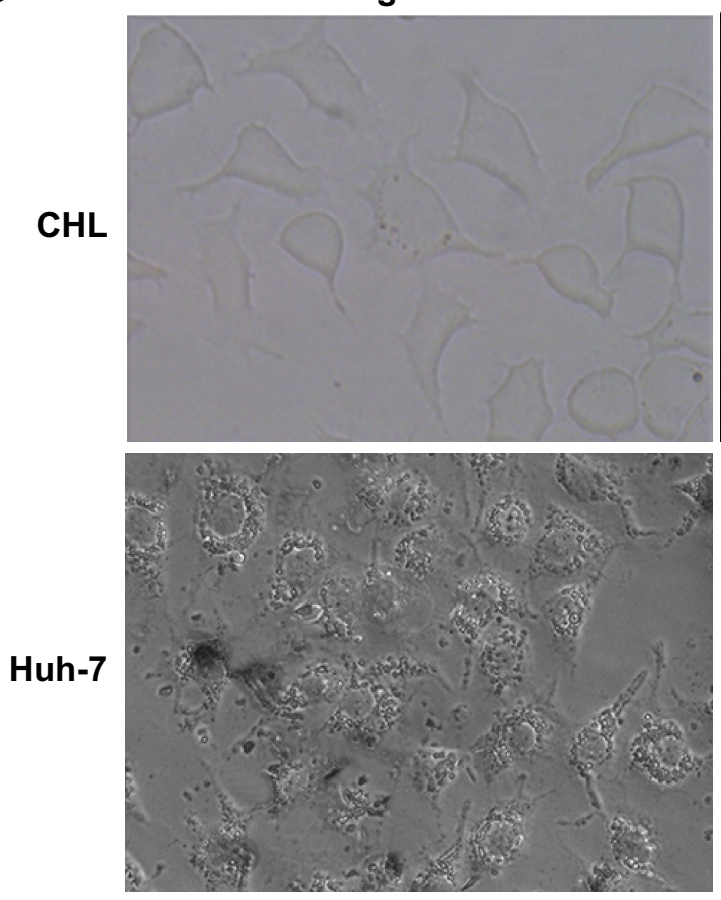

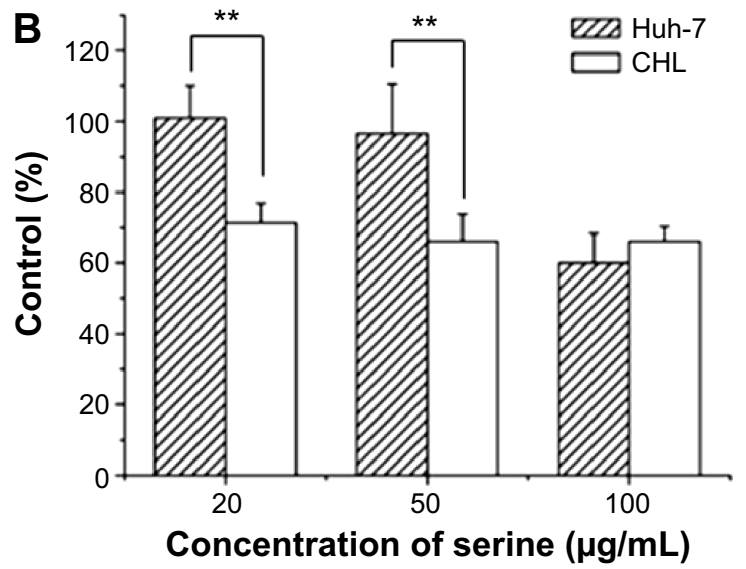

RBITC
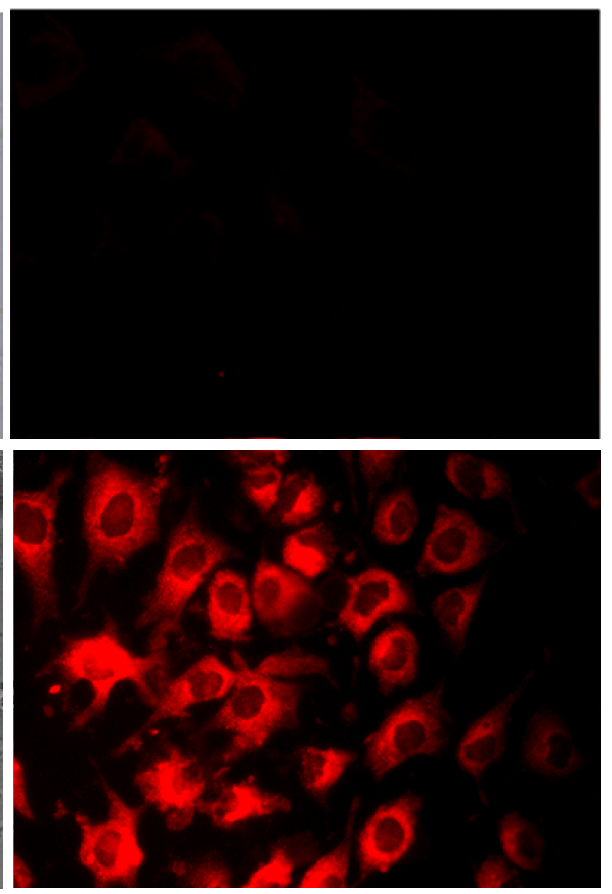

Figure 9 Comparative study on the uptake of RBITC-PFS3 micelles between tumor cells and normal cells.

Notes: (A) Comparative study on uptake of RBITC-PFS3 micelles between Huh-7 cells and CHL cells incubated with $500 \mu \mathrm{g} \mathrm{mL}^{-1}$ RBITC-PFS micelles for 2 hours at $37^{\circ} \mathrm{C}$. (B) Effect of free serine on the uptake of RBITC-PFS3 micelles by Huh-7 and CHL cells. (C) Fluorescence micrographs of Huh-7 cells and CHL cells incubated with $500 \mu \mathrm{g} \mathrm{mL} \mathrm{L}^{-1} \mathrm{RBITC}-\mathrm{PFS} 3$ micelles for 2 hours at $37^{\circ} \mathrm{C}$. $* * \mathrm{P}<0.01$.

Abbreviations: RBITC, rhodamine B isothiocyanate; PFS, poly(L-phenylalanine)-b-poly(L-serine); CHL, Chinese hamster lung. 
even at the concentration of $100 \mu \mathrm{g} \mathrm{mL} \mathrm{m}^{-1}$, which was higher than the normal phenylalanine level in humans.

\section{In vitro tumor targeting of PFS micelles}

$\mathrm{CHL}$ cell was used as a normal cell model to evaluate the tumor targeting of PFS micelles in vitro. There was a striking contrast between the uptake of PFS micelles by the CHL cells and the Huh-7 cells (Figure 9A and C). Under the same conditions, Huh-7 cells showed higher uptake ability to PFS micelles than CHL cells. As shown in Figure 9B, the uptake of PFS micelles by Huh-7 cells was about 1.7-2.7 times higher than CHL cells at 2 hours. The more interesting thing was that free serine had an inhibition on the uptake of PFS micelles by CHL cells at a low concentration of $20 \mu \mathrm{g} \mathrm{mL}^{-1}$, while the uptake by Huh-7 cells was almost not affected by serine at this concentration. The reason might be that the serine receptors of the normal cells are much less than that of the tumor cells and easy to be saturated with serine. As a result, the uptake of PFS micelles by Huh-7 cells was approximately four times higher than CHL cells in the presence of $20 \mu \mathrm{g} \mathrm{mL}^{-1}$ serine. It meant that PFS micelles could selectively concentrate in tumor tissues and were hardly absorbed into normal tissues under physiological conditions.

\section{Conclusion}

A novel amphiphilic PFS polypeptide composed of hydrophobic poly(L-phenylalanine) and hydrophilic poly(L-serine) was synthetized through ring-opening polymerization of L-phenylalanine NCA and $O$-TBDMS-L-serine NCA, followed by deprotective reaction to obtain free hydroxyl groups. It can self-assemble into micelles in water, which are nearly spherical and slightly negatively charged. The average size of PFS micelles is approximately 110-240 nm, which can be significantly influenced by the S/F molar ratio and their relative molecular weights. PFS polypeptides adopt random coil in $\mathrm{pH}$ 7.4 PBS and can partly transform to $\alpha$-helix induced by TFE. PFS micelles with a low CMC of $4.0 \mu \mathrm{g} \mathrm{mL}^{-1}$ were stable in $\mathrm{pH} 5-9$ buffers and serum albumin solution. PFS micelles had a LC of $3.8 \%$ for coumarin- 6 and exhibited a sustained drug release. The uptake of PFS micelles by Huh-7 tumor cells is a time- and concentration-dependent process. The uptake of drugs is consistent with the micelles, which illustrates that the intracellular transport of the loaded drugs highly depends on the micelles. PFS micelles diffuse in the whole cytoplasm, while coumarin-6 assumes localized distribution, thus suggesting that micelles can release the loaded drugs in particular areas. The internalization of PFS micelles is also a temperature- and energy-dependent process, which is involved with clathrin-mediated endocytosis and macropinocytosis. High levels of serine can inhibit the uptake of PFS micelles, which demonstrates that serine receptors do play a positive role in the internalization of PFS. What is more interesting is that the uptake inhibition impacts on normal cells but not on tumor cells at a physiological concentration of serine. The difference in the uptake of PFS micelles is fourfold as high between Huh-7 cells and CHL cells, indicating that PFS micelles have good tumor targeting in vitro. In summary, PFS micelles are regarded as a promising drug delivery system for antitumor therapy.

\section{Acknowledgments}

We are grateful for the financial supports from the National Natural Science Foundation of China (81102381), National Natural Science Foundation of China (81201696), Principal Foundation of Xuzhou Medical College (2010KJZ05), and Priority Academic Program Development of Jiangsu Higher Education Institutions.

\section{Disclosure}

The authors report no conflicts of interest in this work.

\section{References}

1. Service RF. Materials and biology: nanotechnology takes aim at cancer Science. 2005;310:1132-1134.

2. Johnston AP, Such GK, Ng SL, Caruso F. Challenges facing colloidal delivery systems: from synthesis to the clinic. Curr Opin Colloid Interface Sci. 2011;16:171-181

3. Xiong XB, Falamarzian A, Garg SM, Lavasanifar A. Engineering of amphiphilic block copolymers for polymeric micellar drug and gene delivery. J Control Release. 2011;155:248-261.

4. Letchford K, Burt H. A review of the formation and classification of amphiphilic block copolymer nanoparticulate structures: micelles, nanospheres, nanocapsules and polymersomes. Eur J Pharm Biopharm. 2007;65:259-269.

5. Sutton D, Nasongkla N, Blanco E, Gao J. Functionalized micellar systems for cancer targeted drug delivery. Pharm Res. 2007;24: 1029-1046.

6. Toksoz S, Guler MO. Self-assembled peptidic nanostructures. Nano Today. 2009;4:458-469.

7. Zhang XX, Eden HS, Chen XY. Peptides in cancer nanomedicine: drug carriers, targeting ligands and protease substrates. J Control Release. 2012;159:2-13.

8. Rica R, Mendoza E, Lechuga LM, Matsui H. Label-free pathogen detection with sensor chips assembled from peptide nanotubes. Angew Chem Int Ed. 2008;47:9752-9755.

9. Kameta N, Masuda M, Mizuno G, Morii N, Shimizu T. Supramolecular nanotube endo sensing for a guest protein. Small. 2008;4:561-565.

10. Hartgerink JD, Beniash E, Stupp SI. Self-assembly and mineralization of peptide-amphiphile nanofibers. Science. 2001;294:1684-1688.

11. Sargeant TD, Guler MO, Oppenheimer SM, et al. Hybrid bone implants: self-assembly of peptide amphiphile nanofibers within porous titanium. Biomaterials. 2008;29:161-171.

12. Rodríguez-Hernández J, Lecommandoux S. Reversible inside-out micellization of $\mathrm{pH}$-responsive and water-soluble vesicles based on polypeptide diblock copolymers. J Am Chem Soc. 2005;127: 2026-2027. 
13. González-Aramundiz JV, Lozano MV, Sousa-Herves A, FernandezMegia E, Csaba N. Polypeptides and polyaminoacids in drug delivery. Expert Opin Drug Deliv. 2012;9:183-201.

14. Brigger I, Dubernet C, Couvreur P. Nanoparticles in cancer therapy and diagnosis. Adv Drug Deliv Rev. 2002;54:631-651.

15. Kidchob T, Kimura S, Imanishi Y. Amphiphilic poly(Ala)- $b$-poly(Sar) microspheres loaded with hydrophobic drug. J Control Release. 1998;51:241-248.

16. Sugimoto H, Nakanishi E, Yamauchi F, Yasumura T, Inomata K. Aggregate formation and release behaviour of model substances with block copolypeptide containing tryptophan. Polymer. 2005;46:10800-10808.

17. Akagi T, Shima F, Akashi M. Intracellular degradation and distribution of protein-encapsulated amphiphilic poly(amino acid) nanoparticles. Biomaterials. 2011;32:4959-4967.

18. Liang J, Wu WL, Xu XD, Zhuo RX, Zhang XZ. pH responsive micelle self-assembled from a new amphiphilic peptide as anti-tumor drug carrier. Colloids Surf B. 2014;114:398-403.

19. Holowka EP, Pochan DJ, Deming TJ. Charged polypeptide vesicles with controllable diameter. J Am Chem Soc. 2005;127:12423-12428.

20. Kim GM, Bae YH, Jo WH. pH-induced micelle formation of poly(histidine-co-phenylalanine)-block-poly(ethylene glycol) in aqueous media. Macromol Biosci. 2005;5:1118-1124.

21. Holowka EP, Sun VZ, Kamei DT, Deming TJ. Polyarginine segments in block copolypeptides drive both vesicular assembly and intracellular delivery. Nat Mater. 2007;6:52-57.

22. Kukula H, Schlaad H, Antonietti M, Förster S. The formation of polymer vesicles or "peptosomes" by polybutadiene-block-poly(L-glutamate)s in dilute aqueous solution. J Am Chem Soc. 2002;124:1658-1663.

23. Blum JS, Saltzman WM. High loading efficiency and tunable release of plasmid DNA encapsulated in submicron particles fabricated from PLGA conjugated with poly-L-lysine. J Control Release. 2008;129:66-72.

24. Maddocks ODK, Berkers CR, Mason SM, et al. Serine starvation induces stress and p53-dependent metabolic remodelling in cancer cells. Nature. 2013;493:542-546.

25. Yanagida O, Kanai Y, Chairoungdua A, et al. Human L-type amino acid transporter 1 (LAT1): characterization of function and expression in tumor cell lines. Biochim Biophys Acta. 2001;1514:291-302.

26. Fuchs BC, Bode BP. Amino acid transporters ASCT2 and LAT1 in cancer: partners in crime? Semin Cancer Biol. 2005;15:254-266.

27. Kim MS, Dayananda K, Choi EK, Park HJ, Kim JS, Lee DS. Synthesis and characterization of poly(L-glutamic acid)-blockpoly(L-phenylalanine). Polymer. 2009;50:2252-2257.

28. Cheng JJ, Deming TJ. Synthesis of polypeptides by ring-opening polymerization of $\alpha$-amino acid $\mathrm{N}$-carboxyanhydrides. Top Curr Chem . 2012;310:1-26.

29. Fasman GD, Blout ER. The synthesis and the conformation of poly-L-serine and poly-O-acetyl-L-serine. J Am Chem Soc. 1960;82: 2262-2267.

30. Tooney NM, Fasman GD. Synthesis of poly-O-tert-butyl-L-serine and poly-L-serine. Biopolymers. 1968;6:81-96.

31. Tang HY, Yin LC, Lu H, Cheng JJ. Water-soluble poly(L-serine)s with elongated and charged side chains: synthesis, conformations, and cell-penetrating properties. Biomacromolecules. 2012;13: 2609-2615.

32. Planellas M, Puiggalí J. Synthesis and properties of poly(L-lactide)b-poly(L-phenylalanine) hybrid copolymers. Int J Mol Sci. 2014;15: $13247-13266$

International Journal of Nanomedicine

\section{Publish your work in this journal}

The International Journal of Nanomedicine is an international, peerreviewed journal focusing on the application of nanotechnology in diagnostics, therapeutics, and drug delivery systems throughout the biomedical field. This journal is indexed on PubMed Central, MedLine, CAS, SciSearch $®$, Current Contents ${ }^{\circledR} /$ Clinical Medicine,
33. Doruker P, Bahar I. Role of water on unfolding kinetics of helical peptides studied by molecular dynamics simulations. Biophys $J$. 1997;72:2445-2456.

34. Sonnichsen FD, Van Eyk JE, Hodges RS, Sykes BD. Effect of trifluoroethanol on protein secondary structure: an NMR and CD study using a synthetic actin peptide. Biochemistry. 1992;31:8790-8798.

35. Tiffany ML, Krimm S. Effect of temperature on the circular dichroism spectra of polypeptides in the extended state. Biopolymers. 1972;11:2309-2316.

36. Discher DE, Eisenberg A. Polymer vesicles. Science. 2002;297:967-973.

37. Moghimi SM, Hunter AC, Murray JC. Long-circulating and target-specific nanoparticles: theory to practice. Pharmacol Rev. 2001;53:283-318.

38. Honary S, Zahir F. Effect of zeta potential on the properties of nano-drug delivery systems - a review. Trop J Pharm Res. 2013;12:265-273.

39. De Palma R, Peeters S, Van Bael MJ, et al. Silane ligand exchange to make hydrophobic superparamagnetic nanoparticles water-dispersible. Chem Mater. 2007;19:1821-1831.

40. Pyrz WD, Buttrey DJ. Particle size determination using TEM: a discussion of image acquisition and analysis for the novice microscopist. Langmuir. 2008;24:11350-11360.

41. Lu J, Owen SC, Shoichet MS. Stability of self-assembled polymeric micelles in serum. Macromolecules. 2011;44:6002-6008.

42. Lazzari S, Moscatelli D, Codari F, Salmona M, Morbidelli M, Diomede L. Colloidal stability of polymeric nanoparticles in biological fluids. J Nanopart Res. 2012;14:920-929.

43. Zhang LY, Guo R, Yang M, Jiang XQ, Liu BR. Thermo and pH dualresponsive nanoparticles for anti-cancer drug delivery. Adv Mater. 2007;19:2988-2992.

44. Sun J, Chen XS, Deng C, Yu HJ, Xie ZG, Jing XB. Direct formation of giant vesicles from synthetic polypeptides. Langmuir. 2007;23:8308-8315.

45. Wiradharma N, Zhang Y, Venkataraman S, Hedrick JL, Yang YY. Self-assembled polymer nanostructures for delivery of anticancer therapeutics. Nano Today. 2009;4:302-317.

46. Xue YN, Huang ZZ, Zhang JT, et al. Synthesis and self-assembly of amphiphilic poly(acrylic acid- $b$-dl-lactide) to form micelles for pH-responsive drug delivery. Polymer. 2009;50:3706-3713.

47. Rivolta I, Panariti A, Lettiero B, et al. Cellular uptake of coumarin-6 as a model drug loaded in solid lipid nanoparticles. J Physiol Pharmacol. 2011;62:45-53.

48. Lavasanifar A, Samuel J, Kwon GS. Micelles self-assembled from poly(ethylene oxide)-block-poly(N-hexyl stearate L-aspartamide) by a solvent evaporation method: effect on the solubilization and haemolytic activity of amphotericin B. J Control Release. 2001;77:155-160.

49. Lin J, Zhang S, Chen T, Lin S, Jin H. Micelle formation and drug release behavior of polypeptide graft copolymer and its mixture with polypeptide block copolymer. Int J Pharm. 2007;336:49-57.

50. Ye YQ, Yang FL, Hu FQ, Du YZ, Yuan H, Yu HY. Core-modified chitosan-based polymeric micelles for controlled release of doxorubicin. Int J Pharm. 2008;352:294-301.

51. Hillaireau H, Couvreur P. Nanocarriers' entry into the cell: relevance to drug delivery. Cell Mol Life Sci. 2009;66:2873-2896.

52. Rejman J, Oberle V, Zuhorn IS, Hoekstra D. Size-dependent internalization of particles via the pathways of clathrin- and caveolaemediated endocytosis. Biochem J. 2004;377:159-169.

53. Commisso C, Davidson SM, Soydaner-Azeloglu RG, et al. Macropinocytosis of protein is an amino acid supply route in Ras-transformed cells. Nature. 2013;497:633-637.

\section{Dovepress}

Journal Citation Reports/Science Edition, EMBase, Scopus and the Elsevier Bibliographic databases. The manuscript management system is completely online and includes a very quick and fair peer-review system, which is all easy to use. Visit http://www.dovepress.com/ testimonials.php to read real quotes from published authors. 